\title{
CONSTITUTIONAL CHALLENGES OF THE SOUTH: INDIGENOUS WATER RIGHTS IN CHILE ANOTHER STEP IN THE “CIVILIZING MISSION? ${ }^{1}$
}

\author{
Amaya Alvez Marin*
}

This article explores the struggles of indigenous rights based on the adoption of the 1980 Chilean Constitution, under an authoritarian frame, that resulted in water being considered as a commodity and, therefore, subject to radical market rules that serves as a relevant local example in conflict with ratified international treaties. The argument proposes a critical approach to establish a continuum of the recurring rejection of the ancestral beliefs of Indigenous People since colonial times. In light of the actual constituent process for drafting a new constitution in Chile (2015), the article evaluates the emancipatory potential of Chile's early sovereignty proposal on natural resources and later articulations of water as a human right. The argument assesses the possibility of including alternative views in the constituent debate over water, under the light of Third World Approaches to International Law [TWAIL] and Latin American International Law [LAIL] legal scholarship, aiming to find space in the Chilean constitutional realm for non-extractive perspectives.

Dans cet article, l'auteure analyse les combats liés aux droits des peuples indigènes en prenant pour base l'adoption par le Chili, dans un cadre autoritariste, de sa Constitution en 1980, dont il découle que l'eau est considérée comme une marchandise et est, en conséquence, assujettie à des lois du marché radicales. La Constitution chilienne est un exemple local pertinent de mesure incompatible avec les traités internationaux ratifiés. La thèse de l'auteure propose une démarche critique visant à établir la continuité du rejet systématique des croyances ancestrales des peuples autochtones depuis l'époque coloniale. Dans le cadre de l'actuelle procédure constituante de refonte de la Constitution du Chili (2015), l'auteure évalue le potentiel émancipateur du premier projet de souveraineté sur les ressources naturelles et les énoncés postérieurs faisant de

$1 \quad$ This paper is the result of the work done as the Principal Researcher of Fondecyt Iniciación Project No1121371 (20122014), "The Misuse of Comparative Law by the Constitutional Court in Chile" and the work done as an associate researcher of the Water Research Center for Agriculture and Mining (CRHIAM) led by the University of Concepcion, Chile, and funded by the National Research Fund CONICYT/FONDAP, Project $N^{\circ} 15130015$ (2013-2018), and finally the work done as co-investigator of the Fondecyt Project No 1151158 (2015-2018), "The Indigenous Rights Regime and the Chilean State". I acknowledge all funds as a crucial support in developing my current work. I am grateful for academic discussions about the ideas developed in this paper I've had over time with Shin Imai, Jeanne Simon, Ruth Buchanan, Sujith Xavier, Amar Bhatia, Tyler McCreary, Arnulf Becker, Liliana Obregón, Claudio González, Jodi Short, Peer Zumbansen and Sari Graben and for helpful comments received from two blind reviewers. I'm also grateful for editorial help received from Adam Wicks-Arshack, Paris Edwards and Sammy Matsaw. All mistakes are my sole responsibility.

* Amaya Álvez Marín, PhD in Law, York University, Canada. Member of the indigenous Mapuche People. Associate Professor of the School of Legal and Social Sciences.University of Concepción, Chile. 
l'eau un droit de la personne humaine. Sa thèse porte sur la possibilité d'intégrer les points de vue non conventionnels dans le débat constituant sur l'eau, à travers le prisme de la mission universitaire juridique de Third World Approaches to International Law (TWAIL) et de Latin American International Law (LAIL), dans le but de faire une place aux perspectives non orientées sur l'extraction dans le cadre constitutionnel chilien.

\author{
"Indians do not have written laws, but barbaric institutions and customs. \\ They do not have private property. \\ How can we doubt that these people - so uncivilized, so barbaric, \\ contaminated with so many impieties and obscenities - have been justly conquered?" \\ Juan Ginés de Sepúlveda \\ Treaty on the Just Causes of War against the Indians (1550)
}

\title{
I. THE 1980 CHILEAN CONSTITUTION DILEMMA
}

Chilean dictator Augusto Pinochet imposed a new constitution on Chile in 1980, based on a breathtakingly radical application of neo-liberal principles. As pointed out by Roberto M. Unger "in choosing one set of economic institutions over another, we also choose a certain way of living and of connecting with other people." 2 For those who imposed them in the 1970s, the economic foundations of the military dictatorship were referred to as the "brick," through which it would be possible to reconstruct the country. ${ }^{3}$ Neo-liberalism as a societal project was a "brick" that required the destruction of the existing norms and institutions (among them the 1925 Constitution) in favour of economic freedom seen as a precondition of political freedom. ${ }^{4}$ The neo-liberal constitutional project is associated with an ideological expansionism, in which market-modeled societies organize through contracting as a means of collective ordering. Its imposition in Chile necessitated a "shock treatment" described as a "state monopoly on violence actively support[ing] the construction of the neoliberal dream, and the social costs that this construction [deemed]". 5 Neo-liberalism had the consistent purpose of promoting capitalist imperatives against countervailing democratic ones. ${ }^{6}$ Twenty-five years after the restoration of democracy, the model has survived to this day. Reliance on this constitution has been a source of great tension in Chile. However, in a historic move, Chile's current President Michelle Bachelet declared that she would set up a constituent process to draft a new constitution. This process started in October of 2015. ${ }^{7}$ The article supports a contextual approach, one that takes the political and social struggles of Indigenous People seriously in this constituent process, one that ensures an inclusive yet particular

2 Roberto M Unger, What should Legal Analysis Become? (London: Verso, 1996) at 9.

3 Centro de Estudios Públicos CEP, The Brick: Economic Foundations of the Military Government in Chile (Santiago:

Centro de Estudios Públicos, 1992).

4 Milton Friedman, Capitalism and Freedom (Chicago: University of Chicago Press, 1962) at 133.

5 Hans Achterhuis, Rutgerd Boelens \& Margreet Zwarteveen, "Water Property Relations and Modern Policy Regimes: Neoliberal Utopia and the Disempowerment of Collective Action" in Rutgerd Boelens, David Getches and Armando Guevara-Gil, eds, Out of the Mainstream. Water Rights, Politics and Identity (Oxon: Earthscan, 2010$) 27$ at 33.

6 David Singh \& Jedediah Purdy, "Introduction: Law and Neoliberalism" (2014) 77:4 Law \& Contemp Probs 1 at 6.

7 Michelle Bachelet launched the process in October 2015, online: BBC News $<$ http:/www.bbc.com/news/world-latinamerica-34527165 $\geq$. 
regime. However, given our semi-peripheral location, such an approach needs to consider some side effects of this invocation in the constitutional realm. ${ }^{8}$

The dilemma addressed is that Indigenous Peoples, as a unified legal category, have never been recognized in any previous Chilean Constitution ${ }^{9}$. In fact, the Chilean state was formed in 1810 under the premise of excluding those who inhabited the country prior to the conquest by the Spanish empire. This has been called internal colonialism by authors like Ramón Gutiérrez, who proposed the term as an American theory of race that could explain in part the destruction of indigenous values and ways of life. ${ }^{10}$ Although constitutional norms denied formal recognition to Indigenous Peoples, they maintained their distinct languages, beliefs, culture, and social and political norms from the ground up until today. Available official statistics from 2012 indicate that 1.8 million people self-identity themselves as part of one the nine legally recognized indigenous groups. ${ }^{11}$ This figure represents $11.08 \%$ of the total Chilean population. ${ }^{12}$ Combined with constitutional exclusion, these different Indigenous Peoples were directly affected by the neo-liberal 'brick' mentioned above.

Part of the problem is that Chile successfully achieved a measure of political stability in the 1990s, mainly based on economic success, despite being a deeply divided society. Grounded on a transitional model to a democratic regime in the 1990s that discouraged debate and contestation among actors, it imposed a forced constitutional consensus and isolated or excluded others considered deviant and rivals from political debate. ${ }^{13}$ Some constitutional scholars see Chile as a rare example where "an authoritarian constitution, both in its origin and content, may allow for a transition to a stable democracy". 14 Nevertheless, this liberal approach does not take into account the toll paid by limiting popular participation and neutralizing rights arguments that do not fit the strict neo-liberal frame designed by the 1980 Constitution. Moreover, the constitutional process between 1973-1990 was marked by political brutality and mass violations of human rights. One group directly affected by the imposed neo-liberal frame were Indigenous People ${ }^{15}$ who were made invisible and as will be argued later in this paper, the norms and public policies tended to reinforce their cultural, political and economic subordination.

In light of the ongoing debates around the process and the content of a new constitution in Chile, this paper will explore the challenge of Indigenous People's constitutional recognition with a special focus

8 Zoran Oklopcic, "Three arenas of struggle: A contextual approach to the constituent power of 'the people"”, (2014) 3:02

Global Const 200.

9 Chile has had 12 Constitutions in the past: 1811,1812,1814,1818, 1822,1823 (3 texts),1828,1833,1925,1980.

10 Ramón Gutiérrez, "Internal Colonialism: An American Theory of Race” (2004) 1:2 Du Bois Review 281.

11 Law 19.253 (1993) recognized as Indigenous People in Chile: the Mapuche, Aimara, Rapa Nui, Atacameños, Quechuas, Collas, Kawashkar and Yámana. The Diaguita People were included by law 19.253 (2006) after the Pascua Lama case on water rights between an extractive industry and the local community.

12 Statistics available online: Instituto Nacional de Estadistics: Chile $<$ www.ine.cl $>$.

13 Amaya Alvez, "Forcing Consensus: Barriers to Rights-Based Constitutionalism in Chile" in Colin Harvey \& Alex Schwartz, eds, Human Rights Law in Perspective No17, Rights in Divided Societies (Oxford: Hart Publishing, 2012 ) 245 at 246.

14 Esteban Montes \& Tomás Vial, "The Constitution-Building Process in Chile: The Authoritarian Roots of a Stable Democracy" (2005) in The Role of Constitution-building processes in Democratization (International IDEA) at 2, online: International IDEA <www.idea.int/conflict/cbp/>.

15 Throughout this papaer I use the term Indigenous People refering to members of the Aymara and Atacameño People who maintain their own cultural identity. 
on water rights. The claim is not that of a national struggle towards secession but rather the necessity to include indigenous particularities as a claim of political equality. Such a transformation would necessitate a new constitutional framework on natural resources, perhaps following the path of Bolivia in their 2009 Constitution $^{16}$ and creating, in Douzinas words, "a duty to set aside inegalitarian structures." 17

At this historical moment, a critical view based on the tenets of Third World Approaches to International Law [TWAIL] and the particularities of Latin American International Law [LAIL] could provide a fruitful tool to battle against internal colonialism at the constitutional level. ${ }^{18}$

The struggle of our colonial past is partially structured through law. The main claim pushed forward by TWAIL is that mainstream international scholarship reproduces hierarchies and therefore disempowers and subordinates peoples of the Third World. The plight of the Indigenous Peoples throughout the Spanish conquest has been attributed to the idea of "dominium" - private rights and capitalism. The Spanish example is an instance of how international law was positioned to justify empire and colonization in the region. One lesson from scholars like Marti Koskenniemi is the approach to the legacies of the Spanish Empire today. He goes a step further by arguing that Spain's most significant contribution to empire has been the emergence of a global economic system based on private ownership, the search for profit, and continuous warfare. ${ }^{19}$ This perspective was possible through the theory of private dominium rights, based in Roman law, constructed outside the realm of public power through the idea of commutative justice, enforcement of which was organized under the theory of just war. ${ }^{20}$

On this particular topic, the upcoming constituent process represents a double challenge: to be able to confront the effects of radical commodification of water and, for the first time, include Indigenous People and their alternative legalities as relevant factors and actors in the new Constitution. In this sense, the TWAIL perspective could help to unpack the embedded racial hierarchies in global governance debates. $^{21}$ Differences in contemporary legal thought on water almost always portray development techniques to "civilize" societies through economic management. In Chile, Indigenous People are reclaiming the notion of a plurinational state for the up-coming Constitution, a project that Boaventura de Souza has called "intra-state self-determination." 22 To do so, to fully understand the power and social

16 Bolivia's 2009 Constitution, Article 2: "Given the pre-colonial existence of nations and rural native indigenous peoples and their ancestral control of their territories, their free determination, consisting of the right to autonomy, selfgovernment, their culture, recognition of their institutions, and the consolidation of their territorial entities, is guaranteed within the framework of the unity of the State, in accordance with this Constitution and the law." Available online: https://www.constituteproject.org/constitution/Bolivia_2009.pdf

17 Costas Douzinas, Philosophy and Resistance in the Crisis, Greece and the Future of Europe (Cambridge: Polity Press, 2013) at 171.

18 The TWAIL and LAIL movement, which considered a broad critical perspective on international law from the standpoint of the Third World and Latin America respectively, is addressed later in this paper.

19 Marti Koskenniemi, "Empire and International Law. The Real Spanish Contribution" (2011) 61 UTLJ 1.

20 Peter Birks, "The Roman Law Concept of Dominium and the Idea of Absolute Ownership" (1985) Acta Jurídica 1.

21 Makau Mutua, "What is TWAIL?" (2000) 94 Am Soc'y Intl L Proc 31; Antony Anghie, "What is TWAIL: Comment" (2000) 94 Am Soc'y Intl L Proc 39; Sujith Xavier, “Theorising Global Governance Inside Out: A Response to Professor Ladeur" (2013) 3 Transnat'l Leg Theory 268.

22 Boaventura de Souza Santos, "La Reinvención del Estado y el Estado Plurinacional" (2007) Cooperación académica: CENDA - CEJIS - CEDIB: Santa Cruz de la Sierra at18. 
struggles faced at this constituent process, we should acknowledge the relevance of constitutionalism in legitimizing the exercise of public power and, in this concrete example, the interaction between the western neo-liberal imposed legal structure and the Indigenous customary legal system.

Under the neo-liberal frame, the constitutional debate over Atacameños or Aymara water rights needs more than the mere acceptance of pluralism; recognition in the new Constitution needs to pursue the redistribution of power and resources between the Chilean state and Indigenous People through constitutional law. Of course, such redistribution erodes the traditional idea of sovereignty over natural resources as an unconditioned prerogative of the state. ${ }^{23}$ Sovereignty over natural resources has been largely eroded in the 1980 Chilean Constitution through privatization, as Judith Resnik explained as part of a global trend. ${ }^{24}$ Instead, this paper explores a parallel sovereignty of indigenous people over land and natural resources that could be supported by International Law in the current constitutional exercise. ${ }^{25}$

This paper makes this argument through three sections. The first section will expose the efforts of Indigenous People in Chile to end their historical exclusion leading up to the constituent process. The second section will explore the challenges of the radical Chilean constitutional water market for Indigenous People supported by international law. Finally, in the third section, I suggest some lessons from TWAIL and LAIL that could potentially address specific challenges of the Chilean new constitutional framework. ${ }^{26}$

\section{INDIGENOUS PEOPLE IN CHILE: THE END OF THE ROAD FOR HISTORICAL EXCLUSION?}

Endemic efforts have been done as paternalistic attempts to "civilize" Indians by bringing them to the mainstream, in order to include them in a "normalized" way, mostly taking Europe as the natural parameter. Those efforts are based on unequal power structures. ${ }^{27}$ Recognition has also been a pendulum, swinging from forced assimilation to the recognition of distinctiveness with differing allocations of power. The constituent process provides an opportunity to address the claim for political equality further by Mapuche, Aymara and Rapa-Nui People in Chile. ${ }^{28}$

Indigenous People inhabited Chile long before the Spanish invasion started in 1536 with conqueror Diego de Almagro. Human activity can be dated back 33,000 years in Monte Verde, near Puerto Montt

23 UN General Assembly resolution 1803 (XVII) "Permanent Sovereignty over Natural Resources" of 14 December 1962.

24 Judith Resnik, "Globalization(s), Privatization(s), Constitutionalization, and Statization: Icons and Experiences of Sovereignty in the 21st Century" (2013) 11:1 Intl J Const L 162.

25 Federico Lenzerini, "Sovereignty revisited: International Law and Parallel Sovereignty of Indigenous Peoples" (2006) 42 Tex Intl LJ 155.

26 The idea of a Latin American international law has historically been proposed and contested in the 19th and 20th centuries by local international lawyers such as Alejandro Alvarez (Chile) and Carlos Calvo (Argentina), among others.

27 Rutgerd Boelens, David Getches \& Jorge Armando Guevara-Gil, "Water Struggles and the Politics of Identity" in Rutgerd Boelens, David Getches \& Jorge Armando Guevara-Gil, eds, Out of the Mainstream: Water Rights, Politics and Identity (Oxon: Earthscan, 2010) 3 at 6.

28 Pedro Cayuqueo, a Mapuche writer and activistist has been the most vocal author in Chile: Solo Por Ser Indios Y Otras Crónicas Mapuche (Catalonia, 2012); La Voz de los Lankos (Catalonia, 2013); Esa Ruca Llamada Chile (Catalonia, 2014); Huenchumilla. La Historia del Hombre de Oro (Catalonia, 2015). 
in southern Chile. ${ }^{29}$ Indigenous People of the region had their own customary laws, languages, religions and traditions. The conquest and colonization of Latin America, and in particular the one pursued in Chile (1536-1810), annulled any alternative legality to that imposed by the Spaniards. ${ }^{30}$ The Spanish conquest has been traditionally portrayed from a critical perspective as a "black legend" of destruction, abuse and genocide. ${ }^{31}$ At that time, there were some critics among Spanish theologians such as Francisco de Vitoria, Bartolomé de las Casas, Domingo de Soto and Francisco Suárez who confronted the conquest, insisting on the humanity of the Indians based on natural law and reason. Simultaneously, these writers justified the impossibility of indigenous sovereignty. ${ }^{32}$ This popular view of the Spanish conquest has been challenged. For example, Antony Anghie argues that the popular critics of the Spanish empire, such as Francisco de Vitoria, embraced a paternalistic reading and failed to recognize and respect indigenous identity. Moreover, Anghie suggests that Spain was the first European country to colonize and subjugate other cultures as part of a civilizing mission. ${ }^{33}$ The view portrayed in this paragraph is not the one pursued as part of formal primary and secondary education in Chile. On the contrary, Indigenous People are portrayed as "savages", warriors with no formal laws or political organization at the time of the Spanish invasion, and the conquest was justified in order to convert them to Catholicism. No reference is made to the "Encomienda", as a slavery work system, or the greed for gold, silver and natural resources in general as a driving force behind the entire enterprise. ${ }^{34}$

The Spanish Empire did sign treaties with Indigenous Peoples, though they were not regarded as independent nations in their relationship with the Spanish Empire. The most important treaty signed between the indigenous population of Chile and the Spanish empire occurred in 1641, called the Peace of Quilín. Only recently discovered by scholar José Bengoa in the National Library of Spain in Madrid, it established a frontier at the Biobio River and recognized the Mapuche People's right to live independently in the territories of southern Chile. ${ }^{35}$ Moreover, authors like Bartolomé Clavero have argued for the renewed binding value of past treaties between states and Indigenous Peoples. Shortly after Chile achieved independence from Spain, the new republic was recognized by the Mapuche nation through the Treaty of Tapihue (1825). ${ }^{36}$

29 James Adovados \& D. Pedler, "Monte Verde and the Antiquity of Humankind in the Americas" (1997) 71:273 Antiquity 573.

30 Antony Anghie, Imperialism, Sovereignty and the Making of International Law (Cambridge: Cambridge University Press, 2004) at13-32.

31 A classic study is Julián Juderías y Loyot, "La Leyenda Negra y la Verdad Histórica”, Madrid Tip. De la Rev. De Arch., Bibl. y Museos (1914), online: <https://archive.org/details/laleyendanegrayl00jude>.

32 Domingo de Soto, De Dominio (1534); Francisco de Vitoria, Relectio de Indis (1539); Bartolomé de las Casas, Brevísima Relación de la destrucción de Las Indias (1552); and Francisco Suárez, Sobre Las Leyes (1612).

33 Antony Anghie, "Law: Colonial and Postcolonial Realities" (2006) 27 Third World Q 739.

34 This is the way that the best known database for school children deals with the topic. Online: $<$ http://www.icarito.cl/2012/05/404-9476-9-quinto-basico-la-conquista-de-chile-y-sus-particularidades.shtml/>.

35 Jose Bengoa, "El Tratado de Quilín. Documentos adicionales a la Historia de los Antiguos Mapuches del Sur" (2007) Editorial Catalonia.

36 Bartolomé Clavero, "Reconocimiento Mapu-che de Chile: Tratado ante Constitución" (2008) 13 Revista Derechos y Humanidades 13. 
After the coup d'état in 1973, the situation of Indigenous People deteriorated when the authoritarian military dictatorship enacted DL $\mathrm{N}^{\mathrm{o}} 2568$ in $1979 .{ }^{37}$ The real purpose of this legislation was to divide communal or collective indigenous ownership into single and exclusive individual property, but it was presented as an exercise of formal assimilation to eliminate the discrimination and their specific legal arrangements of property over communal lands. Different legal models were portrayed as barriers to Indigenous progress. The law also declared the extinction of all the administrative apparatus that dealt with indigenous matters under the Allende government. This resulted in dispossession of their ancestral lands with the complicity of the formal legal system (lawyers, notaries and the "Conservador" who is responsible for the property register). This system was allowed to break indigenous communities into small pieces with recognition of only private individual property rights over land. This dispossession led to huge resistance by the Mapuches and other Indigenous People against the Chilean state. ${ }^{38}$

The paradigm of uniform rights gradually started shifting in the 1990s. Many Latin American countries started taking legal and political measures to recognize indigenous rights as they were transitioning to democratic regimes. The effort has been to move towards a constitutional recognition, with Raquel Yrigoyen describing the core of the changes as "the recognition of indigenous people as political subjects and not merely as the object of a politics dictated by others; that is, as subjects with rights to control their own institutions and self-define their own destinies." ${ }^{, 39}$ Moreover, in some Latin American countries, the scale of diversity has been seen as one of the central symbols of the transition from dictatorship to democracy in the 1990s. ${ }^{40}$

After the return to a democratic regime in Chile in 1990, and as part of the transitional model, the Chilean government led a special commission on Indigenous People that produced a report called "Historical Truth and a New Deal" that tried to move beyond the traditional neglect. ${ }^{41}$ In the 1990s, some political indigenous leaders like José Mariman proposed an autonomous region as part of a plurinational Chilean state. The legal system addressed very poorly the situation of Indigenous People, which could partially be explained by the political aims of some leaders, like Mariman, to claim secession rather than an institutional readjustment. ${ }^{42}$ Legal arrangements were kept limited, which is illustrated by law 19.253 (1993), that reverted the indigenous question to the previous situation under Allende. Eight Indigenous Peoples were legally recognized in the original text and, in 2006, the Diaguita People were included as the ninth Indigenous group. ${ }^{43}$ Since then, the administrative organization in charge has been the National Commission on Indigenous Development [CONADI], which depends

37 Decree Law published in the Official Gazette on 28 March 1978.

38 Daniel Carter, "Chile's Other History: Allende, Pinochet and Redemocratisation in Mapuche Perspective" (2010) 10:1

Studies in Ethnicity and Nationalism 59.

39 Raquel Yrigoyen, "Legal Pluralism, Indigenous Law and the Special Jurisdiction in the Andean Countries" (2004) 27

Beyond Law 32 at 33.

40 Examples include the constituent processes of Bolivia, Venezuela and Ecuador in recent years.

41 Report available in Spanish at http://biblioteca.serindigena.org

42 José A. Marimán, Autodeterminación. Ideas políticas Mapuche en el albor del siglo XXI (Santiago: Lom ediciones, 2012).

43 Law 20.117 published in the Official Gazette on September 8th, 2006 recognized the existence of the Diaguita People as part of the Indigenous population of Chile. 
nowadays on the Ministry of Social Development. ${ }^{44}$ Michelle Bachelet proposed a debate on indigenous institutional arrangements and allowed a process of prior consultation on the possibility of creating a Ministry of Indigenous Affairs, which was approved by 958 delegates (not without debate) in January $2015 .^{45}$

The situation in Chile moved slowly to a consensus on the relevance of addressing Indigenous People's political situation in the new Constitution. Some pressure was drawn from the outside through a case before the Inter-American System of Human Rights. In, Huenteao Beroiza y otros vs Chile (2004), the government agreed to a friendly settlement and declared that indigenous constitutional recognition was a relevant topic that needed to be promptly tackled. According to the settlement, a resolution was essential to ensuring social unity, peace and public order, and Chile agreed to the constitutional recognition of Indigenous People. ${ }^{46}$

The actual Chilean constituent process requires addressing the political claim to equality made by Aymara, Mapuche and Rapa Nui Peoples. The proposals have been diverse although all of them invite a move beyond liberal democratic hegemony. Some, like the "werken" spokesman of the "Consejo de todas las Tierras" Aucán Huilcaman, proposed a parallel constituent assembly including only Indigenous People. ${ }^{47}$ The difficulty in this case would be to imbricate this institutional setting in the broader constituent process for a new constitution. Others, like Salvador Millaleo (one of the 17 observers of the constituent process designed by Michelle Bachelet in late 2015), proposed that customary law and the mechanisms of information, deliberation, dialogue and decision of Indigenous People should be incorporated as architectural principles of a constituent assembly. Only then could such an assembly generate a legitimate social pact between collective subjects and not just a pact between individuals who can confront internal colonialism. ${ }^{48}$ Both leaders request an indigenous path, one that aims to be respectful of the pre-colonial indigenous worldview and provide intra-state self-determination ending the road of political exclusion and forced assimilation. Nevertheless, Huilcaman seems to aim for a separate constituent process, which is highly unlikely. Conversely, Millaleo requires the adjustment of the actual process to the particularities of the Indigenous People's norms of involvement. This plurality of responses is associated with the need of recognizing Chile as a plurinational state, a model that should also overcome the unitarian political structure in place since colonial times.

44 CONADI's information is available online in Spanish: <www.conadi.cl $>$.

45 Report of the Consultation process can be found here: <www.consultaindigena.gob.cl $>$.

46 Petition 4617/02 Case Huenteao Beraiza y otros vs Chile. The petitioners, Mapuche Pehuenche Families of the Upper Bio Bio, alleged violations of several articles of the American Convention of Human Rights in the implementation of Ralco Hydroelectric Plan Project by Endesa.

47 Aucán Huilcamán announced this before the UN Special Rapporteur on the rights of indigenous peoples in Geneva, July 23 th 2015.

48 Salvador Millaleo, "Una Constitución de los Pueblos Indígenas en Chile: para una legitimidad plurinacional de una Asamblea Constituyente" in Claudio Fuentes and Alfredo Joignant eds, La Solución Consitucional: Plebiscitos, asambleas, congresos, sorteos y mecanismos híbridos (Editorial Catalonia, 2015). 


\section{RADICAL COMMODIFICATION OF WATER IN THE 1980 CONSTITUTION AND THE CHALLENGES FOR INDIGENOUS PEOPLE IN LIGHT OF INTERNATIONAL LAW}

Water serves as a powerful example to show the effects of externally imposed cultural and political values. As noted above, this section focuses on the effects on the water market of the 1980 Constitution and the 1981 Water Code. These legal norms, and the associated system of individual private property over water rights, further marginalized Indigenous People and reinforced their cultural, political and economic subordination. Other scholars have noted how the neo-liberal water modernity project prohibits the existence of a plurality of water rights, water identities and management modes. ${ }^{49}$ The problem in Chile is deepened by the historical argument that indigenous water identity has never been acknowledged by the Chilean state in any constitutional arrangement since Independence in 1810.

\section{A. The Chilean "Laboratory" on Water Rights: National Public Good or Commodity?}

As described by Carl Bauer, water has been a source of power and struggle in Chile and its legal treatment has swung on a "pendulum" from a private property system where the resource could be traded freely to a public interest model based on the public good. ${ }^{50}$ The mainstream account dates the regulation of water use rights back to colonial times and a tradition of irrigation and private canal users' associations. After independence, the pendulum swung towards the public interest governance model in Section 595 of Chilean Civil Code (1855), which declared that "all waters are national goods of public use." ${ }^{51}$ The concept of water use right was further developed through statutory enactment in the 1930 Water Codes, moving to a private property model that recognized water rights consisting of the use, possession and disposal of water allocated..$^{52}$ The 1967 Water Code was aligned with the agrarian reform and went to the public interest end of the pendulum, reinforcing the concept of water as public property while also stressing that water use rights were administrative (rather than private) rights. ${ }^{53}$ The amendments to the 1925 Constitution declared water to be national property of public use and allowed the government to cancel water rights without compensation; due to its public nature, water lost its protection under individual private property rights. ${ }^{54}$ As in many other domains after 1973 , the military coup reversed the "statist" and socialistic tendencies of the previous governments and changed the existing economic paradigm to one based on principles of neo-liberalism. This shift resulted in minimal

49 For example Rutgerd Boelens, David Getches and Armando Guevara-Gil, eds, Out of the Mainstream. Water Rights, Politics and Identity (Oxon: Earthscan, 2010).

50 The most complete analysis of the water marketization in Chile has been written by a US scholar, Carl J. Bauer, Against the Current: Privitization, Water Markets, and the State in Chile (Boston: Kluwer, 1998). Published in Spanish in 2002 as Contra la Corriente: Privatización, Mercados de Agua y el Estado en Chile (www.lom.cl) and more recently Siren Song: Chilean Water Law as a Model for International Reform (Washington, DC: RFF Press, 2004). Published in Spanish as Canto de Sirenas: El Derecho de Aguas Chileno como Modelo para Reformas Internacionales (Bilbao, Spain: Bakeaz, 2004).

51 Civil Code of Chile, 1855, second book, title 3, section 595.

52 Water Code of Chile, 1930, first book, title 2, seection 10.

53 Water Code of Chile, 1967, first book, sections 9 and 11.

54 Constitution of the Republic of Chile of 1925 (as amended), 1967, Law 16.615 published in the Official Gazette on January 20th, 1967 Constitutional Amendment to the 1925 Constitution, sections $10 \mathrm{~N}^{\circ} 10$ on private property rights. 
regulation. The pre-existing protection of water as public property through administrative processes gave way to extractive uses of water for economic profit.

The 1980 Constitution separates water from land regulation in order to attribute a specific cost to each one. It regulates water through property rights, employs markets as allocation mechanisms, incorporates environmental externalities through pricing, and moves away from the traditional concept of common pool resources. According to Chilean constitutional law, "the rights of private individuals, or enterprises, over water, recognized or established by law, shall grant proprietorship to the owners thereof." Citizens could obtain private rights over water by freely applying to the National Water Directorate [DGA] to receive a grant from the government of Chile for new water sources free of charge. Once all rights were allocated, future transfers would take place through the market. This system meant the expropriation and marketization of indigenous communities' existing ancestral rights to water would go to the highest bidder.

International agencies like the World Bank portrayed the Chilean water regime experiment as a very positive one. In a 1996 report, the financial institution praised the trading of water rights because it increases the value of the rights and transfers them to more productive purposes. ${ }^{56}$ During the following decade, many other Latin American countries were forced by international economic institutions like the International Monetary Fund [IMF] and the Inter-American Development Bank to adopt the neo-liberal Chilean example. Among other problems, the imposition of this project could not respect the existing plurality of water rights, water identities and management modes. ${ }^{57}$ The deficiencies of Chile's marketbased policies pertaining to water have only recently become more visible. A report by the Global Water Partnership [GWP] indicated that: "the allocation of water rights without any limits and restrictions quickly gave rise to several problems, such as the accumulation of water rights for hoarding, speculation, and as a means of preventing the entry of competitors into various markets."58 Correspondingly, water resources are now in the hands of the most powerful economic groups: multinational water corporations now own Chile's water supply system, and individuals have become millionaires after requesting free water rights from the state and then selling them at artificially high prices due to their "scarcity". 59

For Indigenous People, the effects of this radical water market have worsened their already invisible status vis-a-vis constitutional law in Chile, in part because they lacked the minimal protections that could have been provided by constitutional recognition. Existing collective indigenous water systems

55 Constitution of the Republic of Chile, , 1980, Chapter III, Section 19 at s 24 protect as a fundamental right private individual property.

56 Mónica Ríos Brehm \& Jorge Quiroz, The Market for Water Rights in Chile: Major Issues (Washington, DC: World Bank Publications, 1995); Robert R Hearne \& Easter K William, Water allocation and water markets : an analysis of gainsfrom-trade in Chile (Washington, DC: World Bank Publications, 1995).

57 Karen Bakker, "The Ambiguity of Community: Debating Alternatives to Private Sector Provision of Urban Water Supply" (2009) 1:2 Water Alternatives 236.

58 Sandy Williams \& Sarah Carriger, "Water and Sustainable Development: Lessons from Chile" (2006) GWP Policy Brief, Working Paper at 3, online: Global Water Partnership $<\underline{\text { http://www.gwp.org/Global/GWP- }}$ CACENA Files/en/pdf/policy brief 2 chile.pdf $>$.

59 Sara Larrain \& Colombina Schaeffer, "Conflicts over Water in Chile: Between Human Rights and Market Rules" (Santiago, Chile: NGO Chile Sustentable, 2010), online: $<$ http://www.chilesustentable.net/wpcontent/uploads/2015/06/Conflicts-over-Water-in-Chile.pdf $>$. 
became illegal and were seen as non-rights. Scholar Milka Castro has noted that the government's invitation was made in order ".. to overcome old, archaic traditions and move on to new modern forms proposing for indigenous marginalization to give way to integration". ${ }^{60}$ Here, we see a new iteration of the idea of dominium as private rights under a forceful capitalist model. Communities lost social cohesion and autonomy after being forced to assimilate to norms and practices that depended on a market-driven water governance model ${ }^{61}$ In recent fieldwork done with Aymara People in Putre, I was struck by how customary water models survive to this day in a subtle way, including rules for dividing the water between community members, deciding when someone broke the water governance rules, and determining how to punish that member of the community. ${ }^{62}$

Another consequence has been inter-sectoral conflicts ${ }^{63}$ that increased judicialization of water conflicts between water users - agriculture, mining, industrial, and indigenous communities. One of the basic problems is that there is no priority given to the water use of particular users over others. ${ }^{64}$ Another source for such conflicts comes from the fact that the same regulations for water management are applied throughout the highly diverse ecosystems found within Chile. Because Chile's constitutional model does not offer a hierarchical use of water, this results in a number of conflicts at various levels. Water conflict intensity is also related to the relative abundance or lack of water resources; in northern Chile, demand surplus leads to conditions of scarcity creating a deficit of up to $40 \%{ }^{65}$ Currently, all uses of water - human, domestic, agricultural and industrial - have the same priority and, if two or more water rights on the same basin are required without sufficient quantity to meet all requirements, the DGA must proceed by public auction. ${ }^{66}$ The present situation is especially troublesome because climate change causes decreasing trends in precipitation that will make scarcity and competition over water resources even worse. In a market system like Chile, the water resources belong to the economically powerful and this ownership system, when accompanied by growing mining and agricultural demand, leaves little hope for the needs of individual citizens, peasants and indigenous communities. Although some projects focus on studying legal hierarchies for water, they mainly address extractive uses and neither propose a method to solve conflicts between users at the same level nor consider Indigenous People as relevant actors. ${ }^{67}$ Although important and relevant, this particular aspect is beyond the scope

60 Milka Castro, "Local norms and competition for water in Aymara and Atacama communities, northern Chile", in R. Boelens and P. Hoogendam, eds, Water Rights and Empowerment (Van Gorcum, 2002) at 187.

61 José Castro, Water, Power, and Citizenship: Social Struggle in the Basin of Mexico (Springer, 2006).

62 The fieldwork done in the Andean Region of Northern Chile is being published in a forthcoming publication on Environmental Justice from a Southern perspective.

63 Inter-sectoral conflicts are understudied in Chile. For a comparative example see: $<$ http://www.cprindia.org/sites/default/files/articles/InterSectoral_Water_Allocation_and_Conflicts.pdf $>$.

64 We treat this issue extensively in a joint-paper by CRHIAM researchers: D. Rivera et al., "Legal Disputes as a Proxy for Regional Conflicts over Water Rights in Chile" (2016) 535 Journal of Hydrology 36.

65 J. Nuñez et al., Chile a secas: Vulnerabilidad chilena frente a la sequía y déficit hídrico extremo desde la interfaz ciencia-política (Instituto de Políticas Públicas UDP, 2013), at 15.

66 The only sensible exception to this rule is found in section 147 (a) of the Water Code. This provision allows "when necessary" to reserve the water resource to supply the population.

67 Maria Ignacia Sandoval, "The absence of regulation of priority uses of water in Chile: a proposal to modify the Chilean Water Code from a comparative law perspective" (2015) 7:7 Journal Justicia Ambiental 133. 
of this paper. However, the complexity of competing demands within and across levels of society, state, and the market underscore the importance of the upcoming constituent process.

From the perspective of access to the basic needs of all human beings, the upcoming constituent process could potentially address such needs by "decommodifying" resources to ensure diverse perspectives on water and not just extractive uses. Scholars such as Fernando Atria and Javier Couso have proposed this idea in Chile from a constitutional perspective. They argue for a regulatory framework based on public resources as an alternative to the existing situation in Chile. ${ }^{68}$ My view is that any alternative framework to water markets needs to address the political, economic and social participation of Indigenous People. It is equally important to debate alternative institutional frameworks before and not after the constituent process takes place in order to ensure sustainable outcomes of a democratic, inclusive, but also pragmatic process.

\section{B. Constitutional Law and International Law Touchdown in the Chilean Arena}

Human rights treaties have enjoyed a special constitutional status in Chile since $1989^{69}$ and therefore add new obligations for Chile in the field of fundamental rights. Chile's international treaty executions are in principle self-executing, although there has been some debate on this point. ${ }^{70}$ Nevertheless, there is a visible tension between the desire of the Chilean government to participate in the international community (as a way of re-legitimizing the Chilean legal system following the 1990s Pinochet authoritarian regime) and the ways in which local legal structures on water remain impervious to international law. A related issue already debated by TWAIL scholars is the requirement to "leave space" for new perspectives on constitutional issues, not only to be infused by international law and particularly human rights, but also to open up for plural constitutional models coming from the outside or co-existing within the boundaries of the same state. ${ }^{71}$ This would need a more nuanced account of constitutional pluralism.

The 1980 Chilean Constitution is unclear on both the incorporation and place of international treaties and international standards within the scheme of internal legal sources. ${ }^{72}$ This gives rise to doctrinal opinions and jurisprudence, which support the recognition that major human rights treaties could take precedence over domestic laws. ${ }^{73}$ The Supreme Court and the Constitutional Tribunal have issued decisions that recognize constitutional supremacy and hierarchy infused by human rights treaties having

68 Fernando Atria, El Otro Modelo: Del Orden Neoliberal al Régimen de lo Público (Santiago: Editorial Debate, 2013).

69 Constitutional amendment through law 18.825 (1989) was part of the transitional arrangements to break the authoritarian features of the Pinochet 1980 Constitution.

70 Liliana Galdámez Zelada, "Criterios del Tribunal Constitucional en el marco de la aprobación de tratados internacionales sobre derechos humanos: el caso del Convenio 169" in María Pia Silva \& Miriam Henríquez, eds, Relaciones del Tribunal Constitucional con los demás órganos del Estado (Editorial Legal Publishing, 2013).

71 Obiora Okafor, "Critical Third World Approaches to International Law (TWAIL): Theory, Methodology, or Both?" (2008) 10 Intl Community L Rev 371.

72 Article 5, subsection 2 of the Constitution of the Republic of Chile in 1980 established the incorporation in the domestic legal system of international obligations on human rights, by way of recognizing them as "a limit to the exercise of sovereignty respect for the essential rights emanating from human nature recognized in the Constitution and by international treaties ratified by Chile which are in force."

73 This presupposes certain mandates, deserving of special consideration is the Pact of San José de Costa Rica, particularly Article 2 (duty to adopt provisions of domestic law) in relation to Article 1 (Obligation to Respect Rights). 
at least similar hierarchy as the 1980 Constitution. $^{74}$ Nevertheless, historically the neo-liberal framework overruled any other international soft or hard law, impeding Chile's ability to meet its international obligations.

The Chilean current model demonstrates that an economic commodity, such as water, can also be considered an essential human right. However, the threshold to determine deprivations of this human right is currently being debated by Chile and impacted parties. Scholars have noted that water is particularly complex as it is essential for human life and critical for ecological functions that justify state intervention. For example, Karen Bakker concludes that the human right to water is incompatible with full privatization, as the disconnection of residential customers for non-payment, sub-par water quality and price regulations would result in human rights violations. ${ }^{75}$ The difficulties and tensions borne out of the duality between commodification and human rights are acknowledged within the 1992 Dublin Principles, which recognize certain fundamental aspects, including notions that: water is a finite and vulnerable resource; there is a need for a participatory approach to water management; recognition of the role of women in the safeguarding of water; and, the economic value of water in all its competing uses and its nature as an economic good. ${ }^{76}$ In 2013, the National Institute of Human Rights challenged the government to address water as a human right. ${ }^{77}$

\section{From Sovereignty Over Natural Resources to Water as a Human Right: The Chilean Context}

International law became global only in the course of the $19^{\text {th }}$ century. As Arnulf Becker explains, international law's range of validity was previously restricted to the interaction between European states. The general characteristics of international classical law were: formalism through the focus on the positive text, sovereignty as an absolute concept and the requirement of a standard of civilization. ${ }^{78}$ In Latin America, the civilization process was projected onto Indigenous People because Latin American elites claimed to own an exclusive right of "guidance to civilization" ${ }^{79}$ As Obregón points out, "the civilization-barbarism dichotomy became the definitive axis." ${ }^{\prime 0}$ Today these distinctions are less visible, because they have been replaced by universal categories like the discourse of human rights. However, on the ground, it's clear that international law works differently at the core than in the periphery. The human rights discourse has been criticized partially for its inability to disrupt the colonial past. ${ }^{81}$

74 Supreme Court decision, ROL N ${ }^{\mathrm{o}} 559$, issued on December 13 th 2006 and Constitutional Court decision, Rol No 786 , issued on June 13th, 2007.

75 K. Bakker, "The 'Commons' versus the 'Commodity': Alter-globalization, Anti-privatization and the Human Right to Water in the Global South” (2007) 39:3 Antipode 439.

76 Declaration of the International Conference on Water and the Environment, "The Dublin Principles on Water and the Environment", Dublin, Ireland, 26-31 January 1992.

77 Chilean National Institute of Human Rights, 2013 Annual Report. Human Rights Situation in Chile, online: El Instituto Nacional de Derechos Humanos <http://www.indh.cl $>$.

78 Arnulf Becker Lorca, "Universal International Law: Nineteenth -Century Histories of Imposition and Appropriation (2010) 51:2 Harv Intl LJ 475 at 484.

79 Douglas Howland, Jean-Louis Halpérin and Arnulf Becker Lorca, Mestizo International Law: A Global Intellectual History 1842-1933, (Cambridge: Cambridge Univeristy Press, 2015) at 72.

80 Liliana Obregón, The Civilized and the Uncivilized", in A Peters and B Fassbender, eds, Oxford Handbook on the History of International Law (Oxford University Press, 2012).

81 Makau Mutua, "Savages, victims, and saviors: the metaphor of human rights", (2001) 42:1 Harv Intl LJ 201. 
However, authors like Mary Ann Glendon underline how Latin America had some insights to offer on the human rights history. ${ }^{82}$ Arnulf Becker stresses the paradoxical history of international law in the $20^{\text {th }}$ century by emphasizing the regional tradition of legal thinking. Becker's mestizo version takes the stance of states on the semi-periphery and argues that "contingent reasons allowed those countries to prevent or resist direct and formal subjugation turning to international law in the hope of narrowing the scope of power core states could legitimately exercise over their territory." 83 Very recently Patrick Macklem has reclaimed the idea of human rights as legal entitlements. ${ }^{84}$

Natural resources and, in particular, water rights have been recognized and conceptualized under international law. In 1952, Chile proposed a draft to the UN that included sovereignty over natural wealth and resources as part of the right to self-determination. ${ }^{85}$ The proposal followed from the decolonization movement advanced by less developed countries seeking to gain control over the natural resources within their territories. This declaration was invoked to legitimate the constitutional amendment of the 1925 Chilean Constitution that allowed nationalization of the copper industry operating in the country in the $1970 \mathrm{~s}^{86}$ The relevance of this principle is such that the International Court of Justice in the 2005 case of Democratic Republic of Congo v. Uganda recognizes it as a principle of customary international law. ${ }^{87}$

Benedict Kingsbury defends the idea of one legal category, Indigenous Peoples, that have great normative power as subjects of contemporary international law. He claims that this principle of international law could also be partially applied to them using the language of human rights as legal entitlements under, for example, ILO Convention No. 169, based on the similarities to the required elements: a territory, a population, the existence of a governmental institution and legal international relationships. ${ }^{88}$ Self-determination in the case of Indigenous Peoples requires the recognition of collective rights, the existence of alternative legalities and a general political space to make decisions. This political space can be part of a broader unity, such as the case of the Plurinational State of Bolivia since 2009. An extensive treatment of the rights to indigenous self-determination and the state, especially from a comparative perspective, is a necessary next step in this project, but won't be addressed now. ${ }^{89}$

82 Mary Ann Glendon, "Forgotten crucible: the Latin American influence on the Universal Human Rights Idea", (2005) 16 Harv Hum Rts J 27.

83 Arnulf Becker Lorca, Mestizo Internatianal Law. A Global Intellectual History 1842-1933 (Cambridge: Cambridge University Press, 2015), at 20.

84 Patrick Macklem, The Sovereignty of Human Rights (Cambridge, MA: Oxford University Press, 2015).

85 The draft is registered as E/CN4/L24 from 16th April 1952.

86 Constitutional Amendment Law 17.450 published in the Official Gazette July 11th, 1971 was presented by the Allende government as a second independence.

87 International Court of Justice, Democratic Republic of Congo v. Uganda, issued on December 19th, 2005, ICJ Reports 2005 at para. 244.

88 Benedict Kingsbury, “'Indigenous Peoples' in International Law: A Constructive Approach to the Asian Controversy” (1998) 92 Am J Intl L 414 at 415.

89 For a good debate on the issue see: Shin Imai, "Indigenous Self-determination and the State" in Benjamin Richardson, Shin Imai \& Kent McNeil, eds, Indigenous People and the Law: Comparative and Critical Perspectives (London: Hart Publishing, 2008). 
It is also relevant to recognize that Indigenous Peoples' ancestral territories are part of their worldview, rejecting an extractive view as the only or prevalent perspective on natural resources. This possibility constitutes a powerful challenge to the basic foundations of international law. For some authors, the frame of rights over natural resources could be applicable because the main resolution on the principle of sovereignty over natural resources talks of all peoples and nations. ${ }^{90}$ Part of the reason for supporting parallel Indigenous Peoples' sovereignty over their territory and resources is the existence of strong ties to their lands, which would allow for sustainable development standards and help to avoid over exploitation.

The formal declaration on permanent sovereignty over natural resources adopted by the General Assembly in 1962 aimed to regulate foreign investment. Sundhya Pahuja explores how the principle of Permanent Sovereignty over Natural Resources [PSNR] drafted by contemporary international institutions was initially presented as a way in which the colonial past could be overcome before ending up as a protection for foreign direct investment. ${ }^{91}$ The question fifty years after its adoption is: On whose behalf and interest has the international law framework worked on the ground? The PSNR started as a political claim of Third World countries, but its national approach over time benefited the economic elites through privatization. One concrete example is the OECD proposal for a multilateral treaty for regulating global investment flows (Multilateral Agreement on Investment, MAI), transforming all natural resources into commodities, representing an international agreement that would be legally binding for member states (including Chile). From a constitutional perspective, such an agreement would be challenging, in part, due to the weakened political and economic power to intervene in the market mechanism in order to preserve local or native perspectives. ${ }^{92}$ The efforts made to build regional solidarity based on international law, exemplified in this paper through the principle of permanent sovereignty over natural resources offered by Alejandro Alvarez, meant considering law and politics as part of the relevant insights. ${ }^{93}$

Sovereignty is addressed as part of a debate held in international law in the 1950s. Nevertheless, a parallel phenomenon occurred in the constitutional realm where privatization and globalization impacted state norms, institutions and affected people on the ground. International human rights law could infuse the new perspective on constitutional sovereignty, imposing limits not only to the actions pursued by the government, but also to private actors on the state's ground. The aim expressed by Judith Resnik would be a renewed version of sovereignty, one where the state creates institutional structures that "express commitments to their values and to develop reciprocal relationships with their populations." ${ }^{94}$

90 Federico Lenzerini, "Sovereignty revisited: International Law and Parallel Sovereignty of Indigenous People" (2006) 42 Tex Intl LJ 155.

91 Sundhya Pahuja, Decolonizing International Law: Development, Economic Growth and the Politics of Universality (Cambridge University Press, 2011) at chapter 4, 95-172.

92 Organisation for Economic Co-operation and Development, Multilateral Agreement on Investment, online: $<$ www.oecd.org/investment/internationalinvestmentagreements/multilateralagreementoninvestment.htm>.

93 Arnulf Becker Lorca, "Alejandro Alvarez Situated: Subaltern Modernities and Modernisms that Subvert" (2006) 19 Leiden J Intl L 879, online: SSRN <http://dx.doi.org/10.2139/ssrn.1370351>.

94 Judith Resnik, "Globalization(s), privatization(s), constitutionalization, and statization: Icons and experiences of sovereignty in the 21st century" (2013) 11:1 Intl J of Con L, 162 at 172. 
There has also been an evolution towards the protection of the environment as natural heritage. For example, the Convention on Biological Diversity focuses its attention on Indigenous Peoples in order to protect their interests in biological resources; also relevant is the adoption of the Akwé: Kon Guidelines regarding water, in 2000. ${ }^{95}$ For example, the Akwé: Kon Guidelines conceptualize traditional knowledge as innovation and practices of indigenous and local communities embodying traditional lifestyles relevant for the conservation and sustainable use of biological diversity. ${ }^{96}$

The Inter-American Court of Human Rights and the Inter-American Commission on Human Rights have also been key actors in the Latin American region for half a century. The leading normative framework is the American Convention on Human Rights, which entered into force in 1978, and was designed to impose specific and legally binding obligations. ${ }^{97}$ For some authors like Samuel Moyn, the reasons to adopt it can be partially found in the U.S. fight, especially throughout the Carter Administration, to resist and contain communism. In Moyn's opinion, the Inter-American system was seen as a diplomatic and rhetorical tool rather than a transformative agent. ${ }^{98}$ Nonetheless, it took shape during the authoritarian regimes because part of the population resisted state repression through human rights terms. ${ }^{99}$ For others because of the particularities of Latin America human rights, and as a response to military regimes in the 1980 s, the Inter-American system turned to a global trend of enforcing human rights standards based on claims of human dignity instead of political struggle under the form of legal entitlements. ${ }^{100}$ To battle this violence, the Court has interpreted S.2 of the American Convention to require member states to respect and guarantee full and free exercise of the rights contained in the treaty, therefore imposing a harmonization requirement. The orthodox way to achieve harmonization is through a democratic legislative process.

Clearly, there is some emancipatory potential in the use of international law for Indigenous People. Consider that there is a growing body of case law of human rights institutions resulting from collisions between the rights of Indigenous People and extractive industries. On the other hand, institutions have also voiced concerns around the right to participation in their territories as established in the Opinion $\mathrm{N}^{\mathrm{o}}$ 4 (2012) by the Expert Mechanism on Indigenous People. ${ }^{101}$ Case law shows how Indigenous People also started looking at international human rights treaties that could allow them to apply and pursue

95 Convention on Biological Diversity, 1992, <https://www.cbd.int/doc/legal/cbd-en.pdf>. Decree 1963 published in the Official Gazette on May 16th, 1995 ratified the Convention on Biological Diversity in Chile. Akwé: Kon Guidelines for the Conduct of Cultural, Environmental and Social Impact Assessments Regarding Developments Proposed to Take Place on, or which are likely to impact on, Sacred Sites and on Lands and Waters Traditionally Occupied or Used by Indigenous and Local Communities, < https:/www.cbd.int/doc/publications/akwe-brochure-en.pdf $>$.

96 The Akwe Kon Guidelines, ibid.

97 Organización de los Estados Emericanos, OASTS 36, 1144 UNTS 123, online: Comisión Interamericana de Derechos Humanos $<$ http://www.cidh.org $>$.

98 Jimmy Carter, US President (1977-1981), signed the Convention in 1977 but the US Senate never followed through with ratification.

99 Samuel Moyn, The Last Utopia: Human Rights in History (Cambridge, MA: Harvard University Press, 2010 ) at 144.

100 In Chile an official number of 2.279 individuals were murdered between September 11, 1973 and March 11, 1990 during the Pinochet regime according to the National Corporation for Reparation and Reconciliation report, online: $<$ http://www.ddhh.gov.cl/ddhh_rettig.html $\geq$.

101 UN Expert Mechanism on the Rights of Indigenous Peoples "Final Study on indigenous peoples and the right to participate in decision-making (A/HRC/18/42). 
justice outside the state boundaries. ${ }^{102}$ For example, the Inter-American Court of Human Rights interpreted in the Saramaka People v. Suriname case that section one of the American Convention grants a right to Indigenous People to freely dispose of their natural wealth and resources in such a way so as not to be deprived of their means of subsistence. If the state would like to pursue a project, it should ensure effective community participation through a duty to actively consult the community and obtain their free, prior and informed consent. ${ }^{103}$ Moreover, the Inter-American Court of Human Rights condemned Chile's procedural treatment of Indigenous People before a court of justice in the 2014 case of Norin Catriman Lonkos Mapuches v. Chile. ${ }^{104}$

In particular, the United Nations has distinguished the right to water as a social and cultural good, as opposed to an economic commodity. ${ }^{105}$ In 2003, the UN noted through General Comment No. 15 of the International Covenant on Economic, Social and Cultural Rights [ICESCR] that articles 11 and 12 of ICESCR provide for a standard of living that includes a right to be protected against hunger and a right to produce, conserve and distribute the products of agriculture. ${ }^{106}$ Section 12 of ICESCR refers to a standard for physical and mental health, and the obligation of states parties to promote public polices to improve hygiene and prevent diseases. ${ }^{107}$ It states that the direct and indirect costs associated with the provision of water must be affordable (s. 12(c)). For people who do not have sufficient means, states are obliged to facilitate and guarantee a necessary supply of water (s. 15). Specifically, with respect to indigenous peoples, it states that access to water in their traditional territories must be protected against all contamination. States must make resources available so that indigenous peoples can plan, exercise and control access to water (s. 16 (d)). The international body gave specific content to the human right to water in 2010 by adopting a UN General Assembly Resolution affirming that water and sanitation rights are "essential for the full enjoyment of life and all human rights." considered to be soft international law, Chile's affirmative vote in the General Assembly should at least mean that its domestic policy is coherent with such an affirmation.

As a complement, the most important international treaty that could be used today in Chile by Indigenous communities is ILO Convention No. 169, which was a revision of the 1957 ILO Convention

102 James Anaya \& Robert Williams Jr, "Protection of Indigenous Peoples' Rights over Lands and Natural Resources under the Inter-American Human Rights System" (2001) 14 Harv Hum Rts J 33.

103 Saramaka People v Suriname (2007) Inter-American Court of Human Rights at paras. 129-134.

104 2014, C-279, CIDH Inter-American Court of Human Rights, case Norin Catriman Lonkos Mapuches v Chile.

105 The regulatory content of the human right to water is addressed in General Comment no 15, which contains an authorized interpretation of articles 11 and 12 of the ICESCR, UN Doc E/c12/2002/11 (Jan. 20, 2003) and in accord with the General Assembly of the United Nations, Resolution 54/292 64/292 (July 29, 2010).

106 PIDESC, UN Doc E/c12/2002/11 (January 20th, 2003), ratification occurred in 1972, however it was published in the Official Gazette only in 1989, which deferred its internal validity as a norm in Chile; International Covenant on Economic, Social and Cultural Rights, 16 December 1966, 999 UNTS 3 (entered into force 3 January 1976).

108 UN Resolution A/RES/64/292 Voted by the General Assembly on July 28th, 2010. 
No. 107. ${ }^{109}$ The main difference is the acceptance of indigenous communities as permanent societies that should be recognized as having rights, such as the right to prior consultation and participation before the enactment of any measure affecting them directly. The text of the Convention establishes standards to comply with the rights to consultation (s.6) and participation (s.7), however neither the Executive nor the Legislature have established requirements for meaningful consultation. Instead, the Chilean government used administrative regulation; decree 124 of $2008^{110}$ established a procedure that was rejected by the Indigenous People. Its replacement, decree 66 of the Ministry of Social Development in $2014,{ }^{111}$ is considered to lack a proper consultation system and is seen as failing to comply with the ILO Conventions. ${ }^{112}$ Nevertheless, very recently, in March 2016, the ILO issued the report of the Committee set up to examine the representation alleging non-observance by the Government of Chile of the Indigenous and Tribal Peoples Convention, 1989 (No. 169), made under article 24 of the ILO Constitution by the First Inter-Enterprise Trade Union of Mapuche Bakers of Santiago. ${ }^{113}$ The report accepted the government's arguments and made some suggestions, starting with a positive approach in a process that is slowly moving forward.

The experience with recent consultation with indigenous people in Chile shows that Chile has fallen short of implementing genuine consultation in good faith with a representative mechanism to adopt decisions in a way that respects the time frames needed to achieve an accord. ${ }^{114}$ It is also relevant how s. 15(1) of ILO Convention No. 169 indicates that the state has the duty to ensure that resources are used for the well being of its people. The concept of indigenous sovereignty is generally aimed at self government related to the exercise of certain sovereign powers that indigenous peoples themselves are in principle entitled to claim and possibly enforce at the national and international levels. As an example of soft law, the 2007 UN Declaration on the Rights of Indigenous Peoples recognizes the most relevant elements of the parallel sovereignty: autonomy or self government; the ownership of their traditional lands including natural resources (with no external interference without effective, free, informed consent); and recognition of their customary law.

This section sought to trace the discussion of Chile's decolonization efforts from the formal articulations in mainstream public international law to underlying contestations and tensions at the domestic level. These tensions include how domestic actors and Indigenous People are pushing back at the sovereign state through human rights articulations, including the human right to water and other uses of water linked to environmental treaties. However, a more refreshing and novel perspective would be to reclaim the original understanding of human rights in the region, using it as described here, to claim a parallel sovereignty over natural resources by Indigenous People. The next section builds on this

109 C107 - Indigenous and Tribal Populations Convention, 1957, No. 107 Convention concerning the Protection and Integration of Indigenous and Other Tribal and Semi-Tribal Populations in Independent Countries (Entry into force: 02 Jun 1959) Adoption: Geneva, 40th ILC session (26 Jun 1957); C169 Convention concerning Indigenous and Tribal Peoples in Independent Countries (Entry into force: 05 Sep 1991) Adoption: Geneva, 76th ILC session (27 Jun 1989).

110 DS 124/2008 Ministry Secretaría General de la Presidencia.

111 DS 66/2014 Ministry of Social Development.

112 ILO 2014 report on Chile claimed an irregular adoption of the consultation internal procedure norms

113 Report GB.326/INS/15/5, online: <http://www.ilo.org/wcmsp5/groups/public/---ed_norm/--relconf/documents/meetingdocument/wcms_462783.pdf $>$.

114 Recent cases of Indigenous consultation end up being judicialized or simply neglected by Indigenous representatives. 
analysis by examining some of the limitations of an approach based solely on international human rights discourse.

\section{LESSONS FROM TWAIL AND LAIL}

\section{A. A Latin American Inter-national Indigenous Perspective}

The history of Indigenous People in Latin America, and their struggles, resonates with the "need for a shared ethical commitment to the intellectual and practical struggle to expose, reform or even retrench those features of the international legal system that help create or maintain the generally unequal, unfair, or unjust global order" ${ }^{115}$ In order for Indigenous People to be considered political subjects, their histories must be taken into account. The hope would be to use TWAIL as a realm where scholars as well as Indigenous People could not only resist, but also transform, the existing law between sovereign nations. TWAIL insights could influence constitutional thinking on the effects of a neo-liberal market system, the use of human rights as the normative frame to address injustices and the persistence of colonial pattern on Indigenous People. It is also about creating space for Third World voices and contextualizing the exercise of TWAIL in order to expand the analysis beyond the nation state. As Pooja Parmar argued, the lives and struggles of Third World or Fourth World Peoples are central to TWAIL. ${ }^{116}$ The approach pursues the objective of showing how the dominant perspective on water as a commodity has deprived Indigenous People of their worldview.

Latin America is considered the historical and geographical colonial site where international law was first enacted. ${ }^{117}$ However, the origins of the Spanish colonial era in 1492 could be approached differently if we take into account the various nations living in the region at the time of the Spanish invasion. Revising the narrative of the colonial legal system is essential in understanding indigenous legal traditions for several critical reasons. First, indigenous culture was rejected outright in the $19^{\text {th }}$ century, pursuing a civilizing project through a whitening of the population resultant from the massive immigration of Europeans. ${ }^{18}$ Secondly, the law was deployed through the adoption of constitutions with the explicit aim of reducing the "barbaric" state, enforcing Spanish as the only civilized language, and establishing the Catholic Church as the official religion. This approach had the lasting effect of punishing other religions, rituals and cultures. ${ }^{119}$

For Koskenniemi, the Spanish empire appeared to prioritize natural resource management through private ownership rather than public resources managed through public institutions. ${ }^{120}$ This approach

\footnotetext{
115 Obiora Okafor, "Newness, Imperialism, and International Legal Reform in our Time: A Twail Perspective" (2005) 43 Osgoode Hall LJ 171.

116 Pooja Parmar, "TWAIL: An Epistemological Inquiry" (2008) 10 Intl Community L Rev at 363.

117 See Martii Koskenniemi, "Empire and International Law. The Real Spanish Contribution” (2011) 61:1 UTLJ 1.

118 A law of colonization was issued by President Manuel Bulnes in 1845, the result of which was a public office for the recruitment of Germans in Munich. In this first wave of immigration, around 40,000 arrived in southern Chile and were allocated territories inhabited by Mapuches but legally considered res nullius, starting an historical and still unresolved problem.

11 Rafael Gaune, "El jesuíta como traductor. Organización, circulación y dinámicas de la Compañía de Jesús en Santiago de Chile, 1593-1598”, (2013) 50 Historia Critica 13.

120 Koskenniemi, supra note 116 at 33.
} 
could be very helpful to address the disastrous effects of the water market with respect of Indigenous People by using the lens of colonialism. Similar to this historical critique, Third World Approaches to International Law is an attractive path for scholars from the periphery. Relying on the foundational work and writings of indigenous leaders like George Manuel, scholars have reiterated Manuel's point that commonalities among the worldviews of Indigenous Peoples, their attachment to the land and their resulting dispossession could be considered a "Fourth World". This framing is characterized by a common experience of colonialism, dispossession and attempted assimilation. ${ }^{121}$ Moreover, the field of constitutional law could learn from a TWAIL path since international law has been the only legal discipline where original contributions to legal academia from Latin America have not been treated as something merely exotic. ${ }^{122}$ Latin-American international scholars such as Liliana Obregón propose filling a gap in the history of international law by considering the existence of a social and legal consciousness called creole, centered on a regional discourse and practice. ${ }^{123}$ This idea suggests "the region's elite often assume themselves as being part of the metropolitan center (as descendants of Europeans) while at the same time challenging the center with notions of their own regional uniqueness (as natives of America)." 124 The role of creole consciousness in the 19th century in Spanish America pursued a nation building process in the benefit of the political elites in power at that time, once again rendering invisible the political, economic and social struggles of Indigenous Peoples.

In particular, the earlier discussion of the Chilean Constitution of 1980 shows how the commodification of natural resources has led to the institutionalization of a hegemonic market system through international legal instruments. ${ }^{125}$ Given the imposition of this neo-liberal brick, cemented by international law, it is worth emphasizing that the TWAIL critique has not only covered economic institutions but also human rights and the way in which the internationalization of property rights has been accompanied by the internationalization of the discourse of human rights. ${ }^{126}$ The idea has been to disrupt the dominant frameworks to propose an alternative emancipatory perspective of indigenous legal traditions as part of international laws with constitutional recognition. In this task TWAIL could provide a challenge to an otherwise mainstream legal discipline, most of the time comfortable within the boundaries of the nation state. Since its very origin in 1900, comparative legal studies aimed at a

121 Amar Bhatia, "The South of the North: Building on Critical Approaches to International Law with Lessons from the Fourth World" (2012) 14:1 Or Rev Intl L 131 at 133, referring to Manuel \& Posluns, The Fourth World (1974).

122 See for example: L Obregón, "Latin American International Law" in D Armstrong, ed, Routledge Handbook of International Law (New York, Routledge, 2009) 154 and more recently "The Civilized and the Uncivilized" in Peters \& Fassbender, supra note 79; and also A Becker Lorca, “Alejandro Alvarez Situated: Subaltern Modernities and Modernisms that Subvert” (2006) 19 Leiden J Intl L 879, online: SSRN < http://dx.doi.org/10.2139/ssrn.1370351> and more recently Mestizo Internatioanl Law. A Global Intellectual History 1842-1933 Cambridge University Press, 2015).

123 See for example Obregón, ibid..

124 Liliana Obregón, "Between Civilisation and Barbarism: Creole interventions in international law" (2006) 27:5 Third World Quarterly 817.

125 Balakrishnan Rajagopal, "From Resistance to Renewal: The Third World, Social Movements, and the Expansion of International Institutions" (2000) 41 Harv Intl L J 529.

126 BS Chimni, "Third World Approaches to International Law: A Manifesto" (2006) 8:3 International Community Law Review 11. 
convergence among legal regimes produced by civilized nations. ${ }^{127}$ The critique is a lack of selfreflection and self-criticism displayed by many comparative lawyers, which tend to conceive themselves as residents of a "non-ethnocentric neutral territory." 28 The openness to comparisons between constitutional orders bears part of the same colonial biases enlightened by TWAIL scholarship. For example, Latin American constitutional comparative lawyers tend to take the Spanish or the U.S. experiences as the parameter for comparison, thus reinforcing a trend, which is tantamount to a form of cultural subordination. A more critical approach would instead unveil how comparative law in postcolonial settings may have perpetuated the historical imbalance of power between the old masters and its former colonies.

There is also an opportunity to infuse the forthcoming catalogue of rights and freedoms by a TWAILinformed approach to human rights. For example, on natural resources and specifically the right to water, the Latin American approach was a legal entitlement as part of a bigger right to selfdetermination. The cornerstone was Resolution 837 (IX) as a direct appeal to sovereignty to defend the equality and autonomy of every country. The right to economic self-determination, as a way to defend the autonomy of the state, was enshrined in Art 1(1) of both 1966 Human Rights Covenants. ${ }^{129}$ Most of the countries in the periphery fought to get the general principle of sovereignty over natural resources recognized, centered on Art. 1 of the Montevideo Convention on the Rights and Duties of States (1934). ${ }^{130}$ Moreover, the declaration indicates that violation of the rights of peoples and nations to sovereignty over their natural wealth and resources is contrary to the spirit and principles of the UN Charter $\left(\mathrm{N}^{\circ} 7\right)$.

\section{B. The Limited Recognition of Indigenous Peoples' Distinctiveness in Chile.}

Colonized people are forced to act within a frame, therefore the proposal is to look to indigenous knowledge as a source to articulate a new model of society. With specific regard to water, the Andean region presents a distinctive irrigation system that brought together people and their attachment to the land and water resources in a decentralized institutional framework. ${ }^{131}$ It is a relevant task to research available information regarding Indigenous legal traditions because, as pointed out by Raquel Irigoyen, "the colonial reality put the native peoples in a condition of political subordination, economic exploitation and cultural devaluation." 132 If we research the normative system previous to the arrival of the Spanish empire, we would discover that the Aymara people's development was possible through a

127 Bénédicte Fauvarque-Cosson, "Development of Comparative Law in France", in M Reimann \& R Zimmermann, eds, The Oxford Handbook of Comparative Law (Oxford, UK: Oxford University Press, 2008), p. 43.

128 Gunter Frankenberg, "Critical Comparisons: Re-thinking Comparative Law" (1985) 26 Harvard Intl L J 411 at 425.

129 ICESCR, supra note 26, in accordance with article 27; International Covenant on Civil and Political Rights adopted and opened for signature, ratification and accession by General Assembly resolution 2200A (XXI) of 16 December 1966 entry into force 23 March 1976, in accordance with Article 49.

130 Montevideo Convention on the Rights and Duties of States, this treaty was signed at the International Conference of American States in Montevideo, Uruguay on December 26, 1933. It entered into force on December 26, 1934. The treaty discusses the definition and rights of statehood.

131 Rutgerd Boelens, Armando Guevara-Gil \& Aldo Panfichi, "Indigenous Water Rights in the Andes: Struggles over Resources and Legitimacy" (2009) 20:5-6 J Water Law 268 at 272.

132 Raquel Yrigoyen, "Legal Pluralism, Indigenous Law and the special jurisdiction in the Andean Countries" (2004) Beyond Law 27 at 32. 
system of irrigation channels for agricultural use that descended from the Andes. Due to its vital role in their lives, water played a part in most ceremonies and rituals besides being a vital element for agriculture and human survival. On the other hand, the Atacameño people have inhabited the driest desert in the world, the Atacama Desert, since 9000 BC. They also developed highly complex irrigation systems through floods that allowed them to cultivate in an area called ayllus. The population settled in the ayllus, developing art offerings for their ancestors at local cemeteries. Another example of the forceful assimilation is that the Atacameño language, Kunza, was abolished during the Spanish conquest. ${ }^{133}$ Today the indigenous statute approved in 1993 recognizes the existence of customs that are enforceable only for members of the same ethic origin. ${ }^{134}$ With reference to water resources, only the Aymara and Atacameños peoples have their ancestral rights recognized in the law. ${ }^{135}$ This legal norm is especially important for Indigenous People that practice terraced agriculture for subsistence crops (corn, quinoa). The indigenous law clearly recognizes customary water rights that have precedence over other uses. The problem is that the law does not contain a specific procedural path to recognize or regularize indigenous ancestral uses of water.

In 2009, the Chilean Supreme Court ruled the ancestral right to water of the Aymara People, including use for humans, animals and small-scale agriculture had precedence over any property right over water based on the 1980 Constitution. It was a groundbreaking decision because it recognized that ancestral uses by Indigenous People prevailed over private property rights over water. ${ }^{136}$ Unfortunately, because Chile lacks a precedent system, there is no uniformity in judicial decisions that could coherently interpret section 64 of law 19.253 (1993) in order to recognize a legal right of Indigenous People over water as part of their worldview. This judicial decision of the Supreme Court is relevant because it uses the collective rights recognized by indigenous law. There is a tension with economic development and also a lack of evidence on historic rights over water resources.

A relevant concern of this work is how Indigenous People in Latin America, and in particular in Chile, consider their legal traditions to be included or excluded by TWAIL scholars; ${ }^{137}$ there is a tension in the TWAIL project between internationalization and localization. ${ }^{138}$ Authors like Luis Eslava and

133 Lautaro Nuñez, "Brief history of Atacameños People”, Public Report for Historical Truth and New Deal with Indigenous People Commission (Santiago, Presidential Commission on Indigenous Affairs, 2008).

134 Section 54, Law 19.253 (1993).

135 Specifically, the only legal right recognized in favour of Aboriginal Peoples in Chile states: S 64, Law 19.253 (1993): Water shall be especially protected for the Aymara and Atacameño communities. They will be regarded as immovable property and prior use of indigenous communities by this law, including water sources that are in the territory of the community, such as rivers, canals, ditches and springs, with preference to the rights that third parties have registered in accordance General Water Code. New water rights on lakes, ponds, springs, rivers and aquifers that supply indigenous communities established by this law should ensure, previously, the normal supply of water to the affected communities will be awarded.

136 Supreme Court decision, Rol N² 2840-08, issued November 25th, 2009.

137 Indigenous scholars in Chile have addressed this topic as part of a bigger struggle: see José Aylwin, Matías MezaLopehandía \& Nancy Yañez, Los Pueblos Ingígenas y el Derecho, (Santiago: Lom Ediciones, 2013); Nancy Yañez \& Raúl Molina, La Gran Minería y los Derechos Indígenas en el Norte de Chile, (Santiago: Lom Ediciones, 2008). The exception is Nancy Yañez \& Raúl Molina, Las Aguas Indígenas en Chile, (Santiago: Lom Ediciones, 2011).

138 John McLeod, ed, The Routledge Companion to Postcolonial Studies (London: Routledge, 2007). 
Sundhya Pahuja emphasize the advantage of critique within the boundaries of the legal system because the radical account would otherwise deprive us of the ability to speak, interact and act. ${ }^{139}$

In the constitutional realm, Latin America has only recently begun to produce alternative legal ideas. Still, most have not left space for an indigenous perspective. ${ }^{140}$ Authors such as Alejandro Medici present the particularities of these constituent processes as endemic to Latin America. ${ }^{141}$ We inhabit the periphery of the western hemisphere and, most of the time, the fight has been to assimilate rather than distinguish ourselves. Following the work of Lopez Medina, it would be wrong to assert either an unchanged reception of the core ideas or just a second-hand peripheral lecture. ${ }^{142}$

\section{CONCLUSION}

This article started from the perspective that Indigenous Peoples as a unified legal category have never been recognized in any of the previous Chilean Constitutions. In fact, the Chilean state was formed in 1810 under the premise of excluding those who inhabited the country prior to the conquest by the Spanish empire. This internal colonialism, a term proposed by authors like Ramón Gutierrez, could in part explain the destruction of indigenous values and ways of life. ${ }^{143}$

In light of the ongoing debates around the process and the content of a new Constitution in Chile, the claim addressed in this paper is not that of a national struggle towards secession but rather the necessity to include indigenous particularities as a claim of political equality. Such a transformation would necessitate a new constitutional framework dealing with natural resources and create, in Douzinas words, "a duty to set aside inegalitarian structures." "144

This article has proposed a contextual analysis of a concrete problem. From the perspective of this article, since the 1980s, Chile has been a site of neo-liberal constitutional experimentation on natural resources. This article has demonstrated the effects of this dispossession and silencing on Indigenous People.

A disruption based on international law from a critical perspective is possible, putting into question the dominant framework of human rights and its application along the lines of the market system. This article rediscovered the particularities that Latin America has offer to this critical enterprise on international law (LAIL), but also tries to reclaim the participation of the region in the Human Rights Movement. It did so by emphasizing the concept of human rights as legal entitlements as part of a bigger right to self-determination. In this new path, a TWAIL perspective could shed light on our colonial past,

\footnotetext{
139 Luis Eslava \& Sundhya Pahuja, "Beyond The (Post) Colonial: TWAIL and the Everyday Life of International Law" (2012) 45:2, JL \& Pol in Africa, Asia and Latin America 195 at 210.

140 Perhaps the only recent examples worth naming are the constitutional processes in Bolivia and Ecuador.

141 Alejandro Medici, "Nuevo Constitucionalismo Latinoamericano y giro decolonial. Seis propuestas para comprenderlo desde un pensamiento situado y critic" en El Otro Derecjo № 48, Debates Constitutionales en Nuetra América. Enfoques y Tendencia (Bogotá: Instituto Latinoamericano para una Sociedad y Derecho Alternativos ILSA, 2013) 19.

142 López Medina Diego Eduardo, "Teoría Impura del Derecho. La Transformación de la Cultura Jurídica Latino Americana" (Bogotá: Legis Editores SA, quinta reimpresión, 2009).

143 Ramón Guttierez, "Internal Colonialism: An American Theory of Race" (2004) 1:2 Du Bois Review 281.

144 Costas Douzinas, Philosophy and Resistance in the Crisis, Greece and the Future of Europe (John Wiley \& Sons, 2013) at 171 .
} 
could invite Indigenous People to make their own political requests regarding the actual constituent process, allowing an institutional framework that could potentially address the social and political struggles of Mapuche, Rapa-Nui and Aymara, among others. Ancestral water rights are a potential way in which the constitutional model could recognize sovereignty over natural resources for Indigenous People.

One concern is the constitutional design of the institutional setting that could allow for such pluralism. The objective of this article has been to open up a conversation to possible southern perspectives of constitutional institutional arrangements, the example being used in this article of Aymara communities in Putre, who have been able to use very limited water resources for centuries in a sustainable way. In this enterprise, it is useful to be aware of the limited effect that the new Chilean constitutional order will have in the global order. Nevertheless, there are some limited gains to be achieved, in terms of uncovering an historical debt with Indigenous People, and at the same time give some hope(s) to the possibility of achieving a different, non-western non-liberal, constitutional arrangement. The new constitution for Chile needs to make sense of the geographical location we live in and the plurality of its inhabitants. This avenue could also open up the space for a conversation of alternative legalities after 500 years of forceful assimilation. 